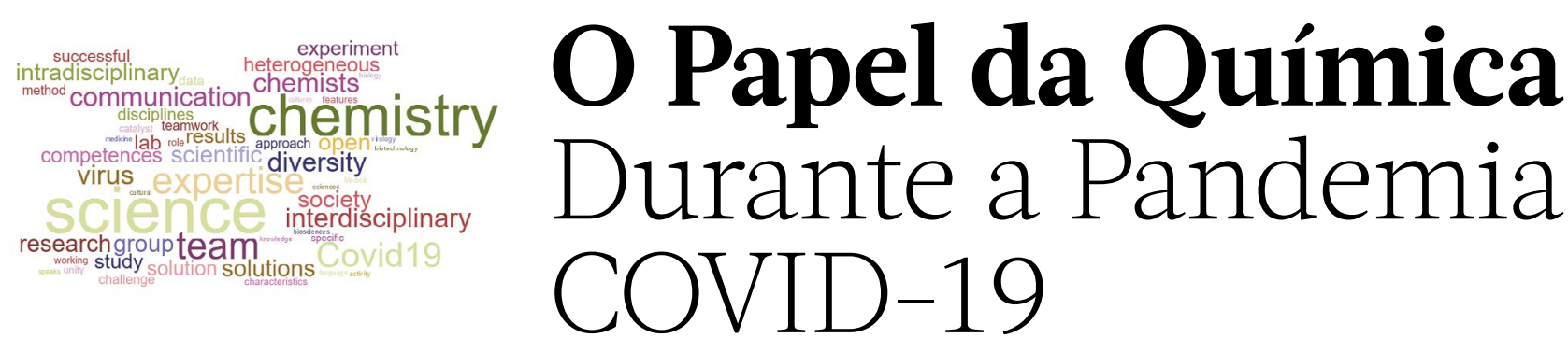

Luigi Campanella, Presidente Sénior do Grupo de Trabalho sobre Ética em Química da EuChemS, escreveu uma contribuição para a EuChemS sobre o papel da Química na pandemia COVID-19. No seu artigo, o Professor Campanella explora possíveis respostas científicas que podem ser encontradas nos conceitos de Ciência Aberta, nomeadamente no acesso facilitado a revistas, jornais e resultados de investigação, Big Data, conhecimento e especialidade. 0 texto integral pode ser encontrado em euchems.eu/the-role-of-chemistry-during-the-pandemic.
Num outro texto, também o papel da Química Analítica no contexto da pandemia foi abordado. Slavica Ražić, Presidente da Divisão de Química Analítica da DAC-EuChemS e Marcela Segundo, Secretária da Divisão, publicaram uma coluna sobre o papel das ciências analíticas durante a atual crise pandémica. Neste artigo, Slavica Ražić e Marcela Segundo também explicam como a DAC-EuChems está a contribuir para o combate à COVID-19. 0 texto integral pode ser encontrado em link.springer.com/ article/10.1007/s00216-020-03007-7.
Bruno Machado

brunofm@fe.up.pt

\title{
Publicação do Relatório Final do Ano Internacional da Tabela Periódica 2019
}

A Assembleia Geral das Nações Unidas proclamou 2019 como o Ano Internacional da Tabela Periódica dos Elementos Químicos (IYPT2019). A celebração, que durou um ano, marcou o 150. aniversário da publicação da classificação sistemática de todos os elementos conhecidos em 1869 por parte de Dmitri Ivanovich Mendeleev no jornal da Sociedade Russa de Química, e cujo resumo foi republicado em alemão (Zeitschrift für Chemie 1869, 12, 405-406). No âmbito das comemorações, foram realizados inúmeros eventos e festividades em mais de 130 países em todo o mundo, incluindo Portugal. Uma compilação dos principais eventos no nosso país pode ser encontrada em iypt2019. pt e no Química (Número 155, Volume 43), que terá em breve uma versão atualizada.

Em outubro de 2020 foi publicado o relatório final do Ano Internacional da Tabela Periódica. Este relatório foi compilado a partir de informações, fotografias e dados fornecidos por um grande número de professores e cientistas de todo o mundo, e pelos parceiros IYPT2019. O relatório encontra-se publicado em iypt2019.org/news/iypt2019-final-report.

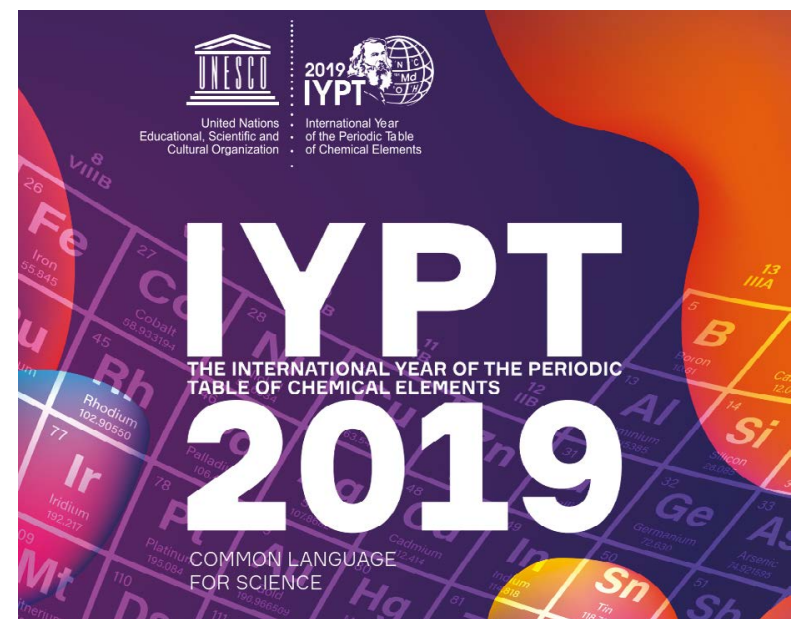

\section{Bruno Machado}

brunofm@fe.up.pt 